Volume 2, Nomor 1, February 2020, p. $13-22$

ISSN 2655-9951 (print), ISSN 2656-0062 (online)

\title{
Diagnosis dan Tatalaksana Pneumonitis Hipersensitif
}

\author{
Muhammad Rizki Akbar ${ }^{1 *}$; Putu Ristyaning Ayu Sangging ${ }^{2}$ \\ ${ }^{1,2}$ Fakultas Kedokteran Universitas Lampung \\ Email: kkgrizky007@gmail.com
}

\begin{tabular}{|c|c|}
\hline ARTICLE INFO & A B S T R A C T \\
\hline $\begin{array}{l}\text { Kata Kunci: } \\
\text { Extrinsic allergic alveolitis } \\
\text { Diagnosis } \\
\text { Pathogenesis } \\
\text { Hypersensitive pneumonitis } \\
\text { Management }\end{array}$ & $\begin{array}{l}\text { Hypersensitive pneumonitis (HP), also known as extrinsic allergic } \\
\text { alveolitis, is a complex pulmonary syndrome mediated by the immune } \\
\text { system and caused by inhalation of various antigens that have } \\
\text { previously been sensitized by the individual. The pathobiology of this } \\
\text { disease is not fully understood, but in addition to the triggers that } \\
\text { initiate the disease, genetic factors tend to be necessary, because only a } \\
\text { small proportion of people are exposed to HP. Because of the lack of } \\
\text { standard diagnostic standards, the diagnosis of HP is not directly } \\
\text { established and depends on several factors, including the history of } \\
\text { exposure, antibodies present in specific antigens, clinical features, } \\
\text { bronchoalveolar lavage (LAB), and radiological and pathological } \\
\text { features. However, in proper management, high suspicion is significant } \\
\text { and can negate the need for more invasive tests. Clinical manifestations } \\
\text { and allergic history vary greatly. Corticosteroids may be useful in acute } \\
\text { episodes to relieve symptoms or chronic progressive disease, but their } \\
\text { long-term effects have never been validated in prospective clinical } \\
\text { trials. We conduct a systematic review of published journals about HP. } \\
\text { The search uses the Pubmed database using the medical term (MeSH) } \\
\text { until January 2020. A total of } 13 \text { journals and one textbook were } \\
\text { identified. }\end{array}$ \\
\hline
\end{tabular}

This is an open access article under the CC-BY-SA license.

\section{PENDAHULUAN}

Pneumonitis Hipersensitif (PH), juga dikenal sebagai alveolitis alergi ekstrinsik, merupakan sindrom kompleks pada paru yang dihasilkan dari penghirupan berulang dan sensitisasi ke berbagai macam antigen aerosol. Manifestasi klinis dan perjalanan penyakit sangat bervariasi, dan tergantung pada faktor-faktor seperti intensitas dan durasi paparan antigen penyebab, sifat antigen, dan faktor host. Imunopatogenesis PH masih kurang dipahami, meskipun hiperreaktivitas dan pembentukan sel $\mathrm{T}$ dan deposisi kompleks imun memainkan peran penting. Khususnya, penyakit ini berkembang 
hanya pada sebagian kecil individu yang terpapar antigen penyebab penyakit potensial, menunjukkan adanya kecenderungan genetik ke PH.

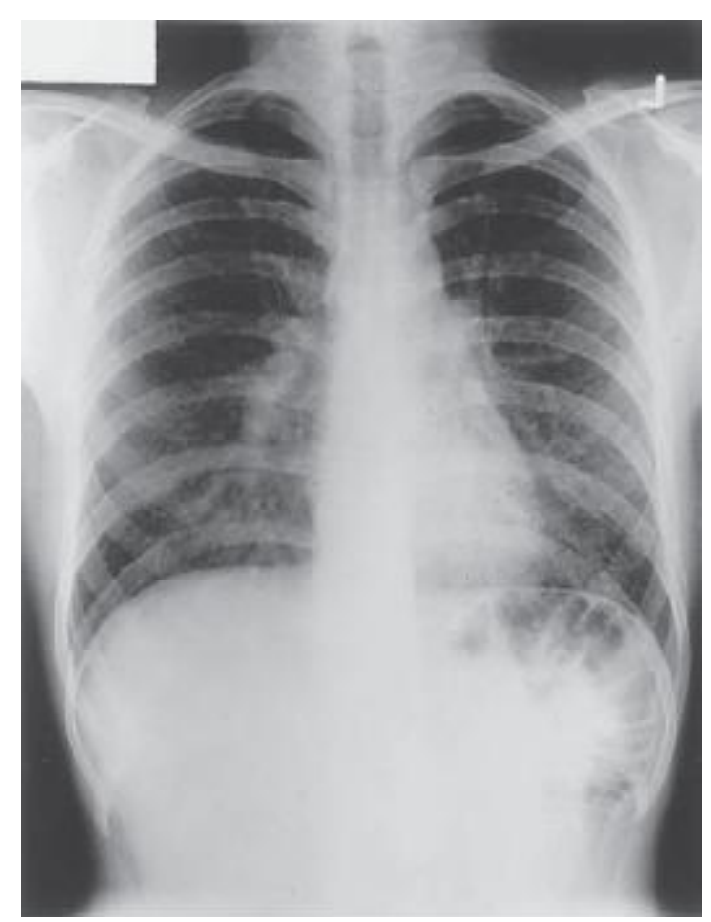

\section{Gambar 1}

Penyakit paru peternak merpati (pigeon breeder's disease) dengan demam, dispnea, dan rasi bibasilar

Menurut data dari pendaftar penyakit paru interstitial (PPI) di 3 negara Eropa, PH menyumbang 4\% hingga $15 \%$ dari semua kasus PPI, tetapi angka ini turun menjadi $2 \%$ menurut penelitian berbasis populasi yang dilakukan di New Meksiko. ${ }^{4}$ Namun, insiden dan prevalensi PH sulit diperkirakan dengan presisi, terutama karena jumlah kasus yang salah diagnosis atau tidak dikenali, serta kurangnya kriteria diagnostik yang seragam. Selain itu, prevalensi penyakit bervariasi dari satu negara ke negara lain (dan bahkan di dalam negara) karena faktor geografis, musiman, dan iklim.,

\section{METODE}

Telah dilakukan literature searching menggunakan search engine PubMed. Total 7392 jurnal yang telah terpublikasi diidentifikasi, 1210 jurnal yang termasuk dalam 5 tahun terakhir. Kami mengidentifikasi beberapa jurnal tersebut yang layak untuk dilakukan review, dan kami menemukan 13 jurnal yang layak dimasukkan untuk di review. Terdapat 6 jurnal systematic review, 5 jurnal penelitian, 1 laporan kasus dan 1 editorial. Dari jurnal-jurnal tersebut diolah menjadi tulisan yang tertulis di pembahasan. Terdapat 1 textbook yang menunjang dalam penulisan review article ini, dalam penganbilan sumber gambar.

\section{HASIL DAN PEMBAHASAN}

Pneumonitis hipersensitif (PH), atau alveolitis alergi ekstrinsik, merupaka spektrum penyakit paruparu interstitial, alveolar, dan bronchiolar yang dihasilkan dari inflamasi yang diinduksi secara imun yang menanggapi inhalasi berbagai bahan yang berbeda yang biasanya organik atau kimia dengan berat molekul rendah atau antigen yang dapat menyebabkan kerusakan paru ireversibel. ${ }^{5}$ Meskipun istilah hipersensitivitas dan alergi, $\mathrm{PH}$ bukanlah penyakit atopik dan tidak terkait dengan 
peningkatan IgE atau eosinofil. ${ }^{6}$ Prevalensi PH cukup bervariasi pada populasi yang berbeda, mungkin karena perbedaan intensitas, frekuensi, dan durasi paparan inhalasi, dan juga mungkin karena faktor inang yang belum diidentifikasi. Setelah dianggap sebagai penyakit yang relatif jarang, penyakit ini menjadi lebih sering dikenal karena kesadaran akan keterbatasan kriteria diagnostik. Di antara peternak merpati, $8 \%$ hingga $30 \%$ anggota klub penangkaran merpati yang berpartisipasi dalam survei menunjukkan bukti $\mathrm{PH}$, yang disebut penyakit peternak merpati (Gambar 1). Di antara petani, 0,5\% hingga 5\% memiliki gejala yang sesuai dengan $\mathrm{PH}$, yang disebut penyakit paru-paru petani. ${ }^{1}$

Populasi yang berisiko dan musim pajanan bervariasi sesuai dengan jenis PH. Misalnya, sebagian besar kasus penyakit paru-paru petani terjadi di daerah beriklim dingin dan lembab di akhir musim dingin dan awal musim semi, ketika petani (biasanya laki-laki) menggunakan jerami yang disimpan untuk memberi makan ternak mereka. Penyakit peternak merpati terjadi terutama pada pria di Eropa dan Amerika Serikat tetapi terutama pada wanita di Meksiko, karena pola paparan yang berbeda, tetapi tanpa preferensi musiman pada kedua populasi. Penyakit pencinta burung di Eropa dan Amerika Serikat terjadi pada subjek yang memelihara burung domestik dan tidak menunjukkan kecenderungan untuk jenis kelamin yang sama. ${ }^{7}$

Berbeda dengan penyakit paru lainnya, ada dominasi aneh (80 - 95\%) dari bukan perokok dalam semua contoh $\mathrm{PH}$, yang secara substansial lebih tinggi daripada proporsi bukan perokok pada orang yang sama-sama terpapar tanpa PH. Mekanisme dari hal ini tidak diketahui, tetapi dapat mencakup efek antiinflamasi nikotin. Temuan klinis ini menunjukkan bahwa peerokok aktif mungkin menjadi bukti terhadap diagnosis $\mathrm{PH}$, meskipun ini belum diamati lebih lanjut. ${ }^{8}$

Tabel 1

\section{Etiologi Pneumonitis Hipersensitif ${ }^{2}$}

\begin{tabular}{|c|c|c|c|}
\hline Class of Antigens & Specific Antigens & Sources & Type of Disease \\
\hline Bacteria & $\begin{array}{l}\text { Saccharopolyspora recivirgula, } \\
\text { Thermoactinomyces vilgaris }\end{array}$ & Mosldy hry, grain & Farmer's lung \\
\hline Fungi, yeasts & $\begin{array}{l}\text { Aspergilhis species } \\
\text { Aspergillus species } \\
\text { Trichosporon cutaneim } \\
\text { Pencilliun species } \\
\text { Penicilinim casei } \\
\text { Atternaria species }\end{array}$ & $\begin{array}{l}\text { Moldy hay, grain } \\
\text { Moldy compost and mushrooms } \\
\text { Contaminated houses } \\
\text { Moldy cork } \\
\text { Moldy cheese or cheese casings } \\
\text { Contaminated wood pulp or dust }\end{array}$ & $\begin{array}{l}\text { Farmer's lung } \\
\text { Mushrooms worker's lung } \\
\text { Japancse summer-type HP } \\
\text { Suberosis } \\
\text { Cheese washer's lung } \\
\text { Woodworker's lung }\end{array}$ \\
\hline \multirow[t]{2}{*}{ Mycobacteria } & Mycobacterium avium-intracellulore & Mold on ceiling, tub water & Hot tub lung \\
\hline & Mycobacterium avium-intracellulare & $\begin{array}{l}\text { Mist from pool water, sprays } \\
\text { and fruntains }\end{array}$ & Swimming pool lung \\
\hline \multirow[t]{3}{*}{ Animal proteins } & $\begin{array}{l}\text { Proteins in avian droppings and serum } \\
\text { and on leathers }\end{array}$ & $\begin{array}{l}\text { Parakeets, budgerigars, pigeons, } \\
\text { parrots, cockatiels, ducks }\end{array}$ & $\begin{array}{l}\text { Pigeon breeder's lung. } \\
\text { bird lancier's lung }\end{array}$ \\
\hline & Avian protcins & Feather bods, pillow, duvets & Feather duvet lung \\
\hline & Silkworm protens & $\begin{array}{l}\text { Dust from silkworm larvae } \\
\text { and cocoons }\end{array}$ & Silk production HP \\
\hline Chemicals & Dusocyanates, trimellitic anhydride & $\begin{array}{l}\text { Polyurcthane forms, spray paints. } \\
\text { dyes, glues }\end{array}$ & Chemical worker's lung \\
\hline
\end{tabular}

Sejumlah besar agen alergi dikaitkan dengan $\mathrm{PH}$, ditunjukkan pada Tabel 1. Beberapa jenis PH tampaknya telah menghilang dari gambaran klinis yang awalnya dijelaskan (mis., Bagassosis) tetapi mungkin ada di daerah dengan pengaturan pertanian atau industri yang serupa. Selain itu, bentukbentuk PH baru lainnya baru muncul (mis. potato riddler's lung dan machine operator's lung). ${ }^{9}$ Hilangnya contoh-contoh PH yang dijelaskan sebelumnya dan munculnya contoh-contoh baru disebabkan oleh perubahan praktik pertanian atau industri yang menghasilkan perubahan paparan 
subjek pada bahan antigenik yang dapat menyebabkan PH. Pada saat ini, penyakit paru-paru petani, penyakit pemelihara burung, paru butuh ventilator, dan PH tipe musim panas Jepang adalah bentuk PH yang paling umum dikenal. 1,7

Pengenalan contoh-contoh baru PH biasanya membutuhkan sekelompok kasus baru dengan riwayat pajanan yang berulang, digarisbawahi pentingnya memperoleh setidaknya riwayat pekerjaan. Sekelompok musisi dapat terjadi $\mathrm{PH}$ dari instrumen yang terkontaminasi dengan Mycobacteria dalam kasus trombonis dalam beberapa kasus saksofonis. ${ }^{4}$ Penggunaan metalworking fluid (MWF) baru menyebabkan PH pada paru-paru operator mesin di sebuah mobil. Pengujian genomik yang sangat sensitif diterapkan pada MWF yang digunakan dalam industri otomotif dan non-otomotif menunjukkan bahwa risiko PH mungkin terkait dengan pola kolonisasi mikroba, khususnya keberadaan Mycobacterium immunogenum. , $^{2,10}$

Manifestasi penyakit ini bisa akut, subakut, atau kronis. Presentasi klinis akut stereotip meliputi demam sementara, hipoksemia, mialgia, artralgia, dispnea, dan batuk yang terjadi 2 hingga 9 jam setelah pajanan dan sembuh dalam 12 hingga 72 jam tanpa perawatan khusus (kadang-kadang lebih lama setelah pajanan yang intens). Pasien yang menunjukkan takipnea, rasi bibasilar, dan kadangkadang sianosis biasanya ada leukositosis pada darah perifer dengan neutrofilia dan limfopenia (tanpa eosinofilia), dan BAL neutrofilia., ${ }^{4,11}$

\section{Manifestasi Klinis}

Presentasi klinis subakut atau intermiten dapat terjadi akibat paparan berulang, dan bermanifestasi seperti batuk produktif, dispnea, kelelahan, dan penurunan berat badan. Mungkin ada limfositosis pada BAL, sering (meskipun tidak selalu) dengan dominasi limfosit T CD8 ${ }^{+11}$

Bentuk kronis secara klinis lebih berbahaya, dan pasien mungkin tidak memiliki riwayat episode akut, tetapi datang dengan batuk, dispnea, kelelahan, dan penurunan berat badan secara bertahap. ${ }^{12}$ Gejala biasanya muncul selama berbulan-bulan hingga bertahun-tahun. Biasanya tidak ada demam, tetapi takipnea dan rhonki kering biasanya ada. Bentuk penyakit ini mungkin sulit dibedakan dari fibrosis paru idiopatik (FPI). Gejala dan tanda kor pulmonale tidak jarang pada keadaan ini. ${ }^{6,8}$

Presentasi klinis yang berbeda (yaitu, akut, subakut, dan kronis) pada PH tidak jelas, tetapi dapat mencakup perbedaan intensitas dan durasi paparan (paparan durasi lama dan intensitas rendah cenderung menyebabkan $\mathrm{PH}$ kronis; intensitas tinggi dan paparan jangka waktu yang cenderung pendek menyebabkan PH akut). Ini paling jelas ditunjukkan dalam PH karena paparan burung. Paparan jangka panjang terhadap antigen burung dalam jumlah rendah dikaitkan dengan PH kronis. Penyakit pencinta merpati memiliki presentasi yang berbeda di wilayah geografis yang berbeda, bermanifestasi sebagai PH akut sebagian dan PH kronis pada lainnya. Paparan merpati yang intermiten terhadap sejumlah besar antigen merpati di Amerika Serikat dan Eropa dikaitkan dengan penyakit akut dan prognosis yang baik, sedangkan paparan kronis pada beberapa merpati di Meksiko dikaitkan dengan penyakit kronis dan prognosis yang jauh lebih buruk. ${ }^{9}$ Di Amerika Serikat dan Eropa, peternak merpati menyimpan hewan mereka di kandang terpisah dari tempat tinggal mereka, dan mereka kunjungi secara berkala sehingga paparannya terputus-putus. Di Meksiko, burung sering dipelihara di tempat tinggal sehingga paparannya konstan. Sangat menarik bahwa antigen burung dapat bertahan di ruangan untuk waktu yang cukup lama (> 18 bulan) setelah pemindahan burung, 12 sehingga orang Meksiko dengan penyakit pemulia merpati dapat terpapar antigen merpati untuk jangka waktu lama bahkan setelah pemindahan merpati. Oleh karena itu, penyakit peternak merpati (pigeon breeder's disease; PBD) di Meksiko menyerupai penyakit pemelihara burung di Amerika Serikat dan Eropa dalam jenis pajanan, presentasi klinis, dan prognosis. ${ }^{7}$ 
Diskusi sebelumnya menunjukkan bahwa PH, dan khususnya $\mathrm{PH}$ kronis, mungkin lebih sering daripada yang sudah terlihat dan mungkin sering membingungkan dalam hal diagnosis dengan penyakit lain, seperti bronkitis kronis atau FPI. Terakhir mungkin sangat penting karena riwayat rinci tidak selalu diperoleh dari pasien dengan FPI, kadar antibodi serum pada agen yang bertanggung jawab untuk PH cenderung berkurang setelah penghentian pajanan, dan pemeriksaan computed tomography $(\mathrm{CT})$ toraks resolusi tinggi pada PH kronis dapat menyerupai FPI. ${ }^{1,9}$

\section{Imunopatogenesis}

PH merupakan hasil dari peradangan parenkim paru yang diinduksi secara imunologis (khususnya, penyakit ini melibatkan alveoli, bronkioli terminal, dan interstitium) yang terjadi pada individu yang rentan dalam menanggapi berbagai antigen. Imunopatogenesis penyakit ini cenderung serupa, terlepas dari agen penyebabnya, dan mekanisme humoral dan seluler tampaknya berkontribusi terhadap perkembangan $\mathrm{PH}^{9}$ Basis genetik $\mathrm{PH}$ masih kurang dipahami dan meskipun beberapa penelitian menunjukkan bahwa polimorfisme dalam human leucocyts antigen (HLA) kelas II meningkatkan risiko $\mathrm{PH}$ pada populasi dengan latar belakang memiliki penyakit genetik, tidak ada faktor genetik yang secara konsisten terkait dengan penyakit tersebut. Jika terpapar agen yang mampu menginduksi $\mathrm{PH}$, sebagian besar individu terjadi toleransi imun, dan menghirup antigen dapat menyebabkan peningkatan ringan pada limfosit lokal, tanpa signifikansi secara klinis. Namun, menurut hipotesis "two-hit", ${ }^{13}$ koeksistensi faktor pemicu (misalnya, antigen) dan faktor pemicu (misalnya, kelainan genetik atau paparan lingkungan tambahan) dapat mengarah pada terjadinya reaksi antibodi berlebihan yang menghasilkan peradangan paru-paru. Pada $\mathrm{PH}$ akut, radang paruparu tampaknya dimediasi oleh kompleks imun, seperti yang dipresentasikan dengan adanya titer IgG endapan spesifik yang tinggi dalam serum, dan peningkatan neutrofil paru yang menjadi penyebab peningkatan frekuensi nafas. ${ }^{11}$ Sebaliknya, PH subakut dan kronik ditandai oleh respon imun yang dimediasi sel $\mathrm{T}$ yang berlebihan, di mana peningkatan migrasi sel $\mathrm{T}$, proliferasi lokal, dan penurunan apoptosis berkontribusi pada karakteristik alveolitis T-limfositik. Proses ini tergantung pada faktor transkripsi STAT-4 dan T-bet, regulator utama dari garis turunan TH1. Sejumlah penelitian juga menunjukkan bahwa respons imun pada $\mathrm{PH}$ terpolarisasi menuju pola diferensiasi seperti TH1, yang sebagian besar dimediasi oleh IL-12 dan IFN- $\gamma^{5}$ Namun telah ditunjukkan bahwa, setelah paparan kronis Saccharopolyspora rectivirgula, sel T CD4 ${ }^{+}$ menunjukkan polarisasi TH17 preferensial dengan ekspresi diferensial IL-17A dan IL-22, menunjukkan bahwa polarisasi ini, bersama dengan upregulasi TH17 sitokin yang memainkan peran penting dalam patogenesis $\mathrm{PH}^{2,8}$

Proses imun yang mengarah pada penyakit persisten dan terjadinya menjadi fibrosis kurang jelas. Namun, fitur yang terkait dengan $\mathrm{PH}$ kronis meliputi peningkatan sel $\mathrm{T} \mathrm{CD}^{+}$dan rasio $\mathrm{CD}^{+} / \mathrm{CD}^{+}$, kecenderungan terhadap diferensiasi sel $\mathrm{T} 2$ dan profil sitokin serta kelelahan sel $\mathrm{T}$ $\mathrm{CD}^{+}$. Peningkatan sel-sel TH17 setelah inhalasi kronis antigen aerosol juga dapat berkontribusi pada terjadinya fibrosis paru. ${ }^{6}$

\section{Gambaran Radiografi}

Radiografi toraks pasien dengan PH akut dan kronis berbeda secara signifikan. Pada PH akut, rontgen toraks menunjukkan radiodensitas nodular difus yang tidak jelas, seringkali dengan area radiodensitas ground-glass atau kadang-kadang bahkan konsolidasi. ${ }^{11}$ Radiodensitas ini cenderung terjadi di lobus bawah dan menyisihkan apeks. Radiodensitas linear (mungkin mewakili area fibrosis dari episode PH akut sebelumnya) juga dapat ditemukan. Kepadatan nodular dan groundglass cenderung menghilang setelah paparan terhenti, sehingga radiografi toraks mungkin normal setelah resolusi episode akut PH (Gambar 2). ${ }^{9}$ 


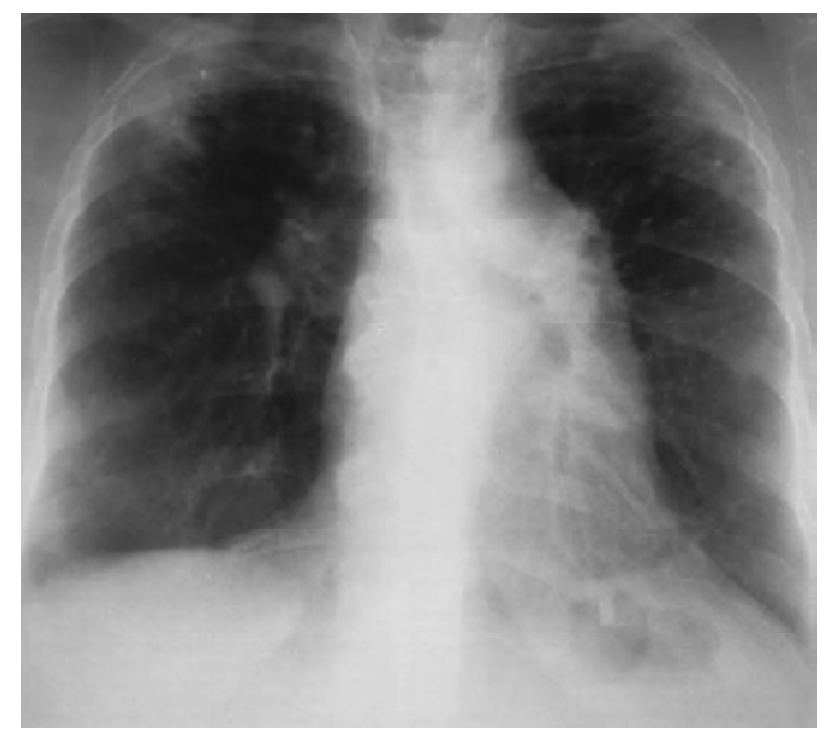

Gambar 2. Radiografi toraks seorang pasien dengan penyakit bird fancier's disease (BFD) yang mengalami dispnea progresif dan penurunan berat badan. ${ }^{3}$

CT scan resolusi tinggi sering menunjukkan kepadatan ground-glass lebih baik daripada radiografi toraks dan kadang-kadang menunjukkan peningkatan radiodensitas paru secara difus. Hal ini juga dapat menjadi normal setelah resolusi episode akut. Efusi atau penebalan pleura, kalsifikasi, kavitasi, atelektasis, radiodensitas terlokalisasi (lesi atau massa koin), dan limfadenopati intrathoraks jarang terjadi. ${ }^{1,6}$

Pada PH kronis, radiografi toraks penting dalam menunjukkan radiodensitas linear dan nodular difus, dengan basis dan dominasi lobus atas serta kehilangan volume (Gambar 3). Efusi dan penebalan pleura sangat tidak biasa, meskipun emfisema subkutan (mungkin sebagai akibat dari ruptur pleura akibat bronkiolitis dan inflasi lobular berlebihan) dapat terjadi. CT scan resolusi tinggi pada pasien dengan $\mathrm{PH}$ kronis menunjukkan beberapa pola. Paling umum ada beberapa nodul centrilobular berdiameter 2 sampai $4 \mathrm{~mm}$ di seluruh bidang paru-paru, dengan beberapa area radiodensitas ground-glass, terutama di lobus bawah (Gambar 4). Tidak seperti sarkoidosis, nodul jarang melekat pada pleura atau bundel bronkovaskular, dan batas antara nodul dan paru-paru di sekitarnya dibatasi dengan baik. Ada juga daerah yang digambarkan dengan baik dari peningkatan radiolusen, yang mungkin merupakan lobulus paru yang terlalu besar yang diobservasi oleh bronkiolus yang tersumbat sebagian. Kerapatan dan mikronoda groundglass cenderung untuk menunjukkan bahwa host sudah terjadi penghentian paparan. Meskipun temuan ini menunjukkan $\mathrm{PH}$, mereka hanya ditemukan pada sebagian (50 - 75\%) pasien dengan $\mathrm{PH}$, dan CT scan beresolusi tinggi pada paru-paru pasien dengan $\mathrm{PH}$ dapat menyerupai pasien dengan FPI. Dalam kasus PH kronis yang berhubungan dengan unggas, konsolidasi honey-comb dan ruang udara pada pemindaian CT resolusi tinggi secara independen terkait dengan peningkatan risiko kematian. ${ }^{8,14}$

\section{Pemeriksaan Laboratorium}

Pasien dengan $\mathrm{PH}$ akut sering memiliki leukositosis darah perifer dengan neutrofilia dan tanpa eosinofilia. Abnormalitas seluler yang menonjol juga dapat dilihat dalam cairan BAL, yang mungkin berguna dalam mendukung diagnosis PH. Pada titik waktu yang lebih besar dari 5 hari setelah paparan terakhir, peningkatan dua hingga empat kali lipat leukosit dan limfosit cairan BAL (biasanya 30 - 70\% dari total sel) sering dicatat. Dalam kebanyakan kasus PH, limfosit cairan BAL hampir semuanya adalah $\mathrm{CD}^{+}$(limfosit $\mathrm{T}$ ), dengan peningkatan sel $\mathrm{CD}^{+}$, sehingga rasio $\mathrm{CD} 4$ : 
CD8 biasanya kurang dari 1 (normalnya 2-2,5 seperti pada darah tepi). Profil ini sangat bervariasi sesuai dengan stadium penyakit. Memang, hanya 33 dari 98 pasien $\mathrm{PH}(34 \%)$ dalam satu seri kasus yang menunjukkan alveolitis $\mathrm{CD} 8^{+}$limfosit. Temuan dari rasio $\mathrm{CD} 4^{+}: \mathrm{CD} 8^{+}$yang lebih tinggi, dan sel T memori CD4 + dan CD8 + yang lebih berdiferensiasi lebih panjang pada cairan BAL pasien dengan $\mathrm{PH}$ kronis dibandingkan dengan yang dari pasien dengan $\mathrm{PH}$ subakut menunjukkan bahwa fibrosis mungkin terkait dengan pergeseran ke arah imunitas Th2 di paru-paru. Selanjutnya, limfositosis BAL dapat bertahan selama bertahun-tahun setelah perbaikan klinis dan hilang dari paparan antigen. Sebaliknya, individu tanpa gejala yang terpajan dapat menunjukkan limfositosis BAL, yang selanjutnya membatasi kegunaannya dalam evaluasi diagnostik. Setelah paparan $(<48$ jam) baru-baru ini, serta pada penyakit lanjut, sering ditandai dengan neutrofilia cairan BAL. Konsentrasi IgG, IgM, dan albumin meningkat dalam cairan BAL, mungkin merupakan manifestasi spesifik dari paru yang mengalami peradangan.,

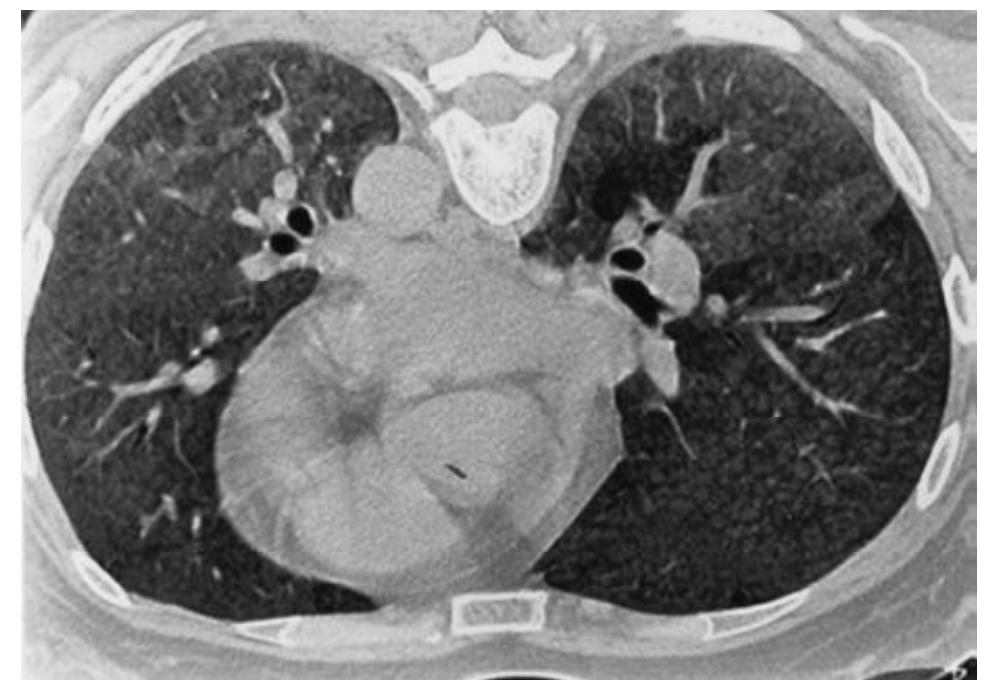

Gambar 3

CT scan resolusi tinggi pada pasien yang tidak merokok dengan paparan burung yang mengalami dispnea yang progresif dan penurunan berat badan serta mengalami hipoksemia dan defek ventilasi restriktif.

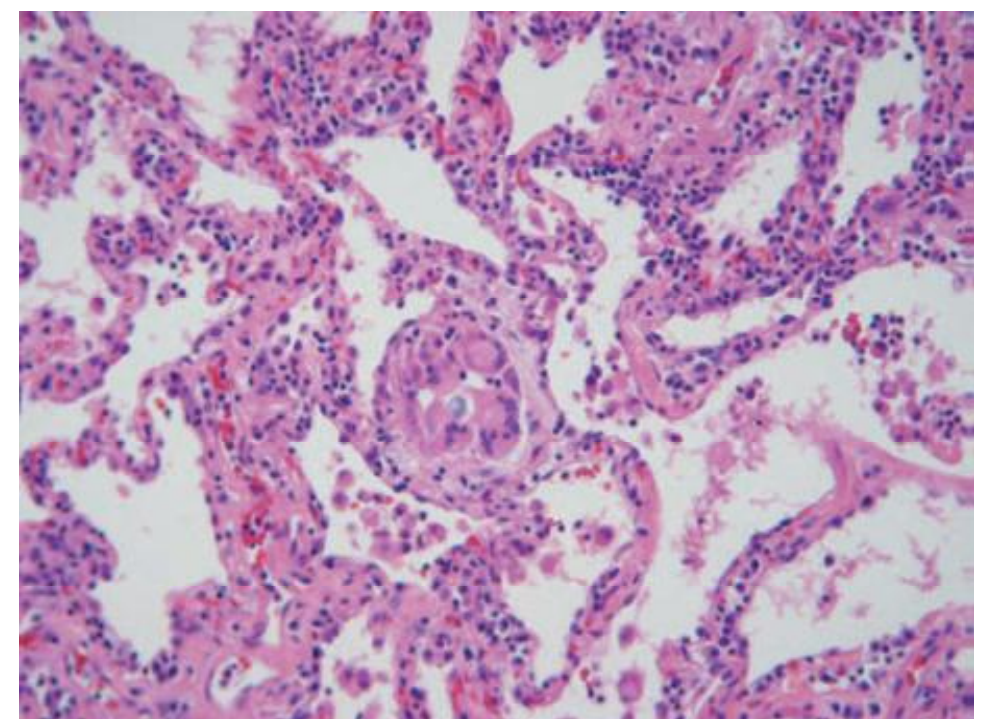

Gambar 4

Tampilan daya rendah $(20 \times)$ dengan pewarnaan $H \& E$ pada biopsi paru dari pasien dengan BFD 


\section{Prognosis}

Prognosis sangat bervariasi dengan jenis PH dan bahkan lokasi geografis penderita. Misalnya, penyakit paru-paru petani memiliki prognosis yang baik di Quebec, bahkan pada petani yang terus bertani. Namun, penyakit paru-paru petani di Finlandia sering mengakibatkan gangguan fisiologis yang signifikan dan bahkan kematian. Penyakit pencinta merpati memiliki prognosis yang baik di Amerika Serikat dan Eropa, sedangkan penyakit yang sama di Meksiko memiliki 30\% mortalitas selama 5 tahun. Alasan perbedaan ini tidak jelas tetapi mungkin termasuk perbedaan dalam sifat antigen dan paparan. ${ }^{6,7}$

Identifikasi antigen penyebab sangat penting untuk penghindaran yang efektif, yang merupakan intervensi utama dalam semua bentuk PH. Ini tidak selalu praktis ketika paparannya adalah pekerjaan, seperti pada penyakit paru-paru petani. Selain itu, sebagian besar petani yang terus terpapar mungkin tidak lebih buruk daripada mereka yang meninggalkan pekerjaan pertanian mereka. ${ }^{14}$ Namun demikian, penghapusan dari paparan antigen yang menyinggung biasanya cukup untuk mengatasi gejala dan kelainan fisiologis. Langkah-langkah untuk mengurangi antigenik mungkin termasuk penggunaan peralatan pelindung dan mengurangi kontaminasi mikroba di rumah atau lingkungan kerja. Pengurangan kelembaban pada lingkungan, perbaikan bahan yang rusak karena air, pembersihan pelembap secara teratur, ventilasi, dan peralatan pendingin udara, semuanya berkontribusi pada pengurangan jamur dan kolonisasi mikroba lainnya, yang dapat menyebabkan sensitisasi. Tidak memelihara burung dari rumah pasien dengan penyakit peternak burung adalah aspek penting dari tatalaksana, tetapi antigen dapat bertahan untuk waktu yang lama meskipun pembersihan menyeluruh dari lingkungan rumah. 5,9

\section{Tatalaksana}

Glukokortikosteroid sistemik biasanya diperlukan untuk mengobati pasien yang sangat bergejala, meskipun tidak ada bukti formal bahwa pengobatan tersebut dikaitkan dengan pengurangan gejala jangka panjang atau kelainan uji fungsi radiologis atau paru. Pengobatan yang biasa adalah prednison atau prednisolon, 40 hingga $60 \mathrm{mg}$ sehari selama 2 minggu, diikuti dengan penurunan bertahap selama 2 hingga 4 minggu. Pasien dengan penyakit paru-paru petani yang diobati dengan prednisolon, dibandingkan dengan mereka yang tidak diobati dengan prednison, menunjukkan resolusi yang sedikit lebih cepat dari beberapa radiologi (kekeruhan ground glass) dan beberapa kelainan fisiologis daripada pasien yang tidak diobati. Namun, tidak ada perbedaan antara kelompok 6 bulan setelah diagnosis PH. Bukti yang disebutkan sebelumnya menunjukkan bahwa steroid sistemik dapat sedikit meningkatkan tingkat resolusi peradangan paru akut tetapi memiliki sedikit atau tidak berpengaruh pada residu PH kronis. ${ }^{6}$

Jika pasien dikeluarkan dari paparan sebelum ada kelainan radiologis atau fisiologis permanen, prognosisnya sangat baik, dengan sedikit bukti efek buruk jangka panjang. Jika pengangkatan dari pajanan tidak memungkinkan, penggunaan masker yang efisien selama pajanan dapat menghasilkan pencegahan $\mathrm{PH}$ akut dan prognosis yang sangat baik. Prognosis sangat bervariasi dengan berbagai jenis PH. Secara umum, penyakit peternak burung membawa prognosis yang lebih buruk daripada bentuk PH lainnya, meskipun bahkan ini sangat bervariasi tergantung pada sifat eksposur tertentu. Tampaknya paparan jangka rendah jangka panjang dikaitkan dengan prognosis yang lebih buruk, sedangkan paparan intermiten jangka pendek dikaitkan dengan prognosis jangka pendek. Sayangnya, banyak pasien dengan PH kronis hadir dengan fibrosis paru dan kelainan fisiologis yang hanya sebagian reversibel setelah penghentian pajanan. ${ }^{1,2}$

Sifat spesifik dari temuan histopatologis pada biopsi pada pasien ini pada saat diagnosis dapat membantu memprediksi perjalanan klinis penyakit berikutnya. Tidak mengherankan, pasien dengan pneumonia yang terorganisir dengan baik seluler memiliki prognosis yang lebih baik dibandingkan dengan nonspecific interstitial pneumonia (NSIP) fibrotik atau lainnya. ${ }^{6}$ 


\section{SIMPULAN DAN SARAN}

PH merupakan penyakit paru yang dimediasi secara imunologis yang kemungkinan dimediasi terutama oleh respons sel T terhadap antigen yang dihirup. Diagnosis memerlukan anamnesis yang cermat, tes laboratorium yang sesuai, dan biopsi paru pada kasus tertentu. Menghindari pajanan biasanya berkaitan dengan prognosis yang baik, dan kortikosteroid diindikasikan pada pasien dengan gejala berat. Karena paparan lingkungan yang terus berubah, contoh-contoh PH baru terusmenerus berkembang, dan menjadi tantangan yang berkelanjutan pada pasien dengan penyakit paru interstitial yang tidak terdefinisi.

Diperlukan penelitian atau review lanjut tentang pneumonitis lain untuk menyingkirkan diagnosis selain pneumonitis hipersensitif.

\section{DAFTAR PUSTAKA}

1. Selman M, Pardo A, King TE. Hypersensitivity Pneumonitis. Am J Respir Crit Care Med. 2012;186(4):314-24.

2. Spagnolo P, Rossi G, Cavazza A, Bonifazi M, Paladini I, Bonella F, et al. Hypersensitivity Pneumonitis : A Comprehensive Review. J Investig Allergol Clin Immunol. 2015;25(4):23750.

3. Gifford AH, Enelow RI. Hypersensitivity Pneumonitis. In: Fishman's Pulmonary Diseases and Disorders. Philadelphia: McGraw-Hill; 2015. p. 875-83.

4. Quirce S, Vandenplas O, Campo P, Cruz MJ, de Blay F, Koschel D, et al. Occupational hypersensitivity pneumonitis: an EAACI position paper. Allergy. 2016 Jun;71(6):765-79.

5. Shiroshita A, Tanaka Y, Nakashima K, Furukawa Y, Kataoka Y. Diagnostic accuracy of specific IgG antibodies for bird fancier's lung: a systematic review and meta-analysis. Ann Transl Med. 2019 Nov;7(22):655.

6. Miller R, Allen TC, Barrios RJ, Beasley MB, Burke L, Cagle PT, et al. Hypersensitivity Pneumonitis A Perspective From Members of the Pulmonary Pathology Society. Arch Pathol Lab Med. 2018 Jan;142(1):120-6.

7. Vasakova M, Morell F, Walsh S, Leslie K, Raghu G. Hypersensitivity Pneumonitis : Perspectives in Diagnosis and Management. Am J Respir Crit Care Med. 2017;196(6):6809.

8. Churg A, Ryerson CJ. The Many Faces of Hypersensitivity Pneumonitis. Chest. 2017;152(3):458-60.

9. Barnes H, Morisset J, Molyneaux P, Westall G, Glaspole I, Collard HR. A systematically derived exposure assessment instrument for Chronic Hypersensitivity Pneumonitis. Chest. $2020 \mathrm{Jan} ; 3692(20): 30022-32$.

10. Chandra H, Yadav JS. T-cell antigens of Mycobacterium immunogenum, an etiological agent of occupational hypersensitivity pneumonitis. Mol Immunol. 2016 Jul;75:168-77.

11. De Sadeleer LJ, Hermans F, De Dycker E, Yserbyt J, Verschakelen JA, Verbeken EK, et al. Impact of BAL lymphocytosis and presence of honeycombing on corticosteroid treatment effect in Fibrotic Hypersensitivity Pneumonitis: a retrospective cohort study. Eur Respir J. 2020 Jan;1:1901983. 
12. Filev PD, Little BP, Duong P-AT. Second-Opinion Reads in Interstitial Lung Disease Imaging: Added Value of Subspecialty Interpretation. $J$ Am Coll Radiol. 2020 Jan;1(19): 1546.

13. Kuranishi L, Storrer K. Chronic hypersensitivity pneumonitis. J Asthma Allergy. 2016;9:171-81.

14. Walscher J, Gross B, Morisset J, Johannson KA, Vasakova M, Bruhwyler J, et al. Comorbidities and survival in patients with chronic hypersensitivity pneumonitis. Respir Res. 2020 Jan;21(1):12. 